\title{
Site-Directed Mutagenesis of Myoglobin for Studies of Their Interaction with Iron(III) by Multi-Spectroscopic Techniques
}

\author{
Qian Tang, ${ }^{1,2}$ Xiao-Jun Peng, ${ }^{1}$ Hong-Yu Cao, ${ }^{2}$ Yan-Jie Yang, ${ }^{2}$ Jing Ma, ${ }^{2}$ \\ Jing-Yun Wang, ${ }^{1}$ and Xue-Fang Zheng ${ }^{2}$ \\ ${ }^{1}$ Faculty of Environmental and Biological Science and Technology, Dalian University of Technology, Dalian City 116024, China \\ ${ }^{2}$ Liaoning Key Laboratory of Bioorganic Chemistry, Dalian University, Dalian City 116622, China \\ Correspondence should be addressed to Jing-Yun Wang; wangjingyun67@126.com or Xue-Fang Zheng; dlxfzheng@126.com
}

Received 25 April 2012; Revised 11 July 2012; Accepted 12 July 2012

Academic Editor: Daniel Oscar Cicero

Copyright (C) 2013 Qian Tang et al. This is an open access article distributed under the Creative Commons Attribution License, which permits unrestricted use, distribution, and reproduction in any medium, provided the original work is properly cited.

In order to investigate how the amino acids on the surface of myoglobin molecule influence myoglobin's structure and function, a variety of spectroscopy techniques were applied in the study of the interaction between Fe(III) and myoglobin (wild type and its mutants, D44K, D60K, and K56D). The results demonstrate that Fe(III) can quench the fluorescence of wild type and mutants of myoglobin, and the quenching mechanisms are static quenching. It is found that the binding distance between Fe(III) and myoglobin mutants gets smaller, the binding capacity increases by the values of binding constant and the bimolecular quenching constant as well as the binding distance. Those data also indicate that the metal ion Fe(III) can interact strongly with myoglobin mutants. The three-dimensional conformation change after surface amino acids are replaced is detected by the UV absorption spectroscopy and fluorescence spectroscopy, which make mutants become more dynamic and change its function and interaction with $\mathrm{Fe}(\mathrm{III})$ strongly.

\section{Introduction}

Proteins have a variety of important physiological functions. They participate in every reaction of the living body and are essential for the translation of the genetic code of life, transcription of the information, and replication of DNA. Metal elements play an important role in the whole system of life. The most prominent feature for metal elements is to lose electrons and become ions with charges. As a result, metal ions exist in biological fluids in various forms and interact with biomolecules in many ways, which perform kinds of functions in organism, such as electron transfer, oxygen carrier, and enzyme active center [1]. Among the different metal elements, iron is one of the most essential trace elements to maintain life, and it executes many functions, such as transport and storage of oxygen, the conversion of energy in the body, drug metabolism, and decomposing and eliminating of active oxygen.

Myoglobin (Mb) is an oxygen-binding protein found in the muscle tissues of vertebrates in general and in almost all mammals [2]. Due to its simple structure and important biological activity, it has been the model protein for the study of proteins' interaction with their ligands. The research on interaction between proteins and ligands help to deeply realize the function of proteins in vivo. For a long time, it is believed that the amino acid residues on the surface of proteins exposed to the solvents have very little impact on the proteins' function [3]. However, Hoffman and his fellows [4] have found that the electron transfer rate between myoglobin mutant D44K and cytochrome b5 increased by an order of magnitude. They also obtained a triple mutant, in which three acidic surface residues surrounding the $\mathrm{Mb}$ (horse) heme (Asp44, Asp60, and Glu85) are replaced by Lys $[\mathrm{Mb}(+6)]$, and binding and reactivity progressively become correlated by the mutations, the results exhibit both strongly enhanced binding to b5 (bovine) and intracomplex ET from the triplet state of $\mathrm{Zn}$-deuteroporphyrin $(\mathrm{ZnD})$-substituted $\mathrm{Mb}$ to the $\mathrm{Fe}^{3+}$ b5 heme $\left(\mathrm{Fe}^{3+} \mathrm{P}\right)[5,6]$. Our group has discussed the issue of interactions between myoglobin and its mutants with ligands, such as gas $[7,8]$, surfactants $[9,10]$, and hydrogen 
peroxide [11], and has obtained many valuable results. The plethora of work performed by Rifkind, Saltman, Gray, Mauk and others in the 1980s with oxyMb and various ferriccomplexes revealed that two distinct mechanisms by which sperm whale myoglobin reduces, respectively, complexes of $\mathrm{Fe}(\mathrm{III})$ and $\mathrm{Cu}(\mathrm{II})$ and, in turn, is oxidized to metmyoglobin have been characterized $[11,12]$. Our group also have investigated the interactions between wide-type myoglobin with various metal ions [13-15]. However, detailed study on interactions between metal ions and its mutants has not been reported yet. In order to clarify the impact of specific amino acids residues on the surface of $\mathrm{Mb}$ on the structure and function of myoglobin, in the present study, PCR site-directed mutagenesis technique was used to obtain myoglobin mutants D44K, D60K, and K56D and then a variety of spectrographic methods were adopted to study the interactions between metal ion Fe(III) and myoglobins (wild type and mutants).

\section{Experimental}

2.1. Instrument and Reagent. Instruments. FP-6500 fluorescence spectrophotometer (Jasco, Japan), J-810 Circular Dichroism (Jasco, Japan), V-560 UV-visible Spectrophotometer (Jasco, Japan), and F-12 cooling and heating circulator (Julabo, Germany).

Reagent. Wild-type myoglobin sample (Sigma, USA) was proved to be oxymyoglobin (namely the metMb [16]). $5 \times$ $10^{-6} \mathrm{~mol} \cdot \mathrm{L}^{-1}$ metMb stock solution in $\mathrm{NaHPO}_{4}-\mathrm{NaH}_{2} \mathrm{PO}_{4}$ buffer $(0.05 \mathrm{~mol} \cdot \mathrm{L}, \mathrm{pH}=7.40)$ was prepared and stored in a refrigerator $\left(4^{\circ} \mathrm{C}\right) .1 \times 10^{-2} \mathrm{~mol} \cdot \mathrm{L}^{-1} \mathrm{FeCl}_{3}$ stock solution was made with $\mathrm{FeCl}_{3} \cdot 6 \mathrm{H}_{2} \mathrm{O}(\mathrm{AR})$. All of the experimental water is ultrapure water.

\subsection{Experimental Methods}

2.2.1. Preparation of the $M b$ Mutants [3, 17]. In our experiment, we use two-steps $\left(\mathrm{NH}_{4}\right)_{2} \mathrm{SO}_{4}$ precipitation, Sephadex-G100 gel filtration, DEAE ion-exchange chromatography to purify the proteins. The concentration of myoglobin is measured by UV/VIS spectrophotometer $\left(\varepsilon_{409}=\right.$ $\left.157 \mathrm{mM}^{-1} \cdot \mathrm{cm}^{-1}[18]\right)$.

2.2.2. Spectrometry. Pipette $3 \mathrm{~mL}$ of $5 \times 10^{-6} \mathrm{~mol} \cdot \mathrm{L}^{-1} \mathrm{metMb}$ solution in $1 \mathrm{~cm}$ quartz cuvette, and then place it in the V-560 $\mathrm{UV}$-Vis spectrophotometer, add a certain amount of Fe(III) solution (cumulative total volume was less than $40 \mu \mathrm{L}$ ) with a microinjector(each) and mix them, put it aside for $4 \mathrm{~min}$ at $298 \mathrm{~K}$, and then measure the UV absorption spectra of the coordinative reaction of metMb with $\mathrm{Fe}(\mathrm{III})$. Measure the fluorescence spectroscopy, synchronous fluorescence spectroscopy, and circular dichroism spectroscopy according to the above steps. Measurement for mutants is the same as well.
TABLE 1: The bimolecular quenching constant $\left(K_{q}\right)$, the dynamic quenching constants $\left(K_{s v}\right)$, the correlation coefficients $(R)$ in SternVolmer curve.

\begin{tabular}{lccc}
\hline Mb and Mutants & $T / \mathrm{K}$ & $K_{q} / \mathrm{L} \cdot \mathrm{mol}^{-1} \cdot \mathrm{s}^{-1}$ & $K_{s v} /{\mathrm{L} \cdot \mathrm{mol}^{-1}}^{12}$ \\
\hline $\mathrm{Mb}(\mathrm{WT})$ & 289 & $1.12 \times 10^{12}$ & $1.12 \times 10^{4}$ \\
& 298 & $1.04 \times 10^{12}$ & $1.04 \times 10^{4}$ \\
& 310 & $0.903 \times 10^{12}$ & $0.903 \times 10^{4}$ \\
\hline $\mathrm{Mb}(\mathrm{D} 44 \mathrm{~K})$ & 289 & $1.51 \times 10^{12}$ & $1.51 \times 10^{4}$ \\
& 298 & $1.40 \times 10^{12}$ & $1.40 \times 10^{4}$ \\
& 310 & $1.29 \times 10^{12}$ & $1.29 \times 10^{4}$ \\
\hline & 289 & $1.14 \times 10^{12}$ & $1.14 \times 10^{4}$ \\
$\mathrm{Mb}(\mathrm{D} 60 \mathrm{~K})$ & 298 & $1.09 \times 10^{12}$ & $1.09 \times 10^{4}$ \\
& 310 & $1.04 \times 10^{12}$ & $1.04 \times 10^{4}$ \\
\hline & 289 & $1.7 \times 10^{12}$ & $1.7 \times 10^{4}$ \\
$\mathrm{Mb}(\mathrm{K} 56 \mathrm{D})$ & 298 & $1.62 \times 10^{12}$ & $1.62 \times 10^{4}$ \\
& 310 & $1.46 \times 10^{12}$ & $1.46 \times 10^{4}$ \\
\hline
\end{tabular}

\section{Result and Discussion}

\subsection{Interaction between Protein and Fe(III)}

3.1.1. Ultraviolet Absorption Spectroscopy. Figure 1 shows the UV absorption spectra of Fe(III) with myoglobin and its mutants. Near $280 \mathrm{~nm}$, Mbs' absorption intensity increases gradually with the increase of the concentration of Fe(III), and there is a slight blue shift. Mbs' absorption peak at the $280 \mathrm{~nm}$ is caused by the transition of the aromatic heterocyclic of the tryptophan and tyrosine in the peptide chain [19]. The above data show that Fe(III) can interact strongly with Mbs, which indicate that they form a new complex and the conformation of $\mathrm{Mb}$ molecules change. The aromatic heterocyclic hydrophobic groups of the tryptophan and tyrosine residues inside the molecules of exposed Fe(III) expose when they interact with $\mathrm{Fe}(\mathrm{III})$, as the hydrophobic interactions between hydrophobic groups inside the molecules weaken and polarity enhance, the $\pi-\pi^{*}$ and $n-\pi^{*}$ transition energy increases, which make the absorption peak of proteins move towards the short wavelength direction and the peak intensity gradually increase.

\subsubsection{Fluorescence Spectrum. (1) Fluorescence Quenching} Mechanism. Figure 2 is the fluorescence spectra of the interaction between Fe(III) and different Mbs, respectively. As it is showed from the fluorescence spectra, Fe(III) causes regularly the fluorescence quenching of the proteins, which proves that the interaction and energy transfer between the proteins and $\mathrm{Fe}(\mathrm{III})$. The experimental result is consistent with that of the UV spectra. The fluorescence spectra are not distorted, which indicates that the energy transfer between them is nonradiative transfer [20].

Fluorescence quenching can be caused by dynamic quenching and static quenching. The dynamic quenching follows the following equation of Stern-Volmer [21-23]:

$$
\frac{F_{0}}{F}=1+K_{q} \tau_{0}[Q]=1+K_{s v}[Q]
$$




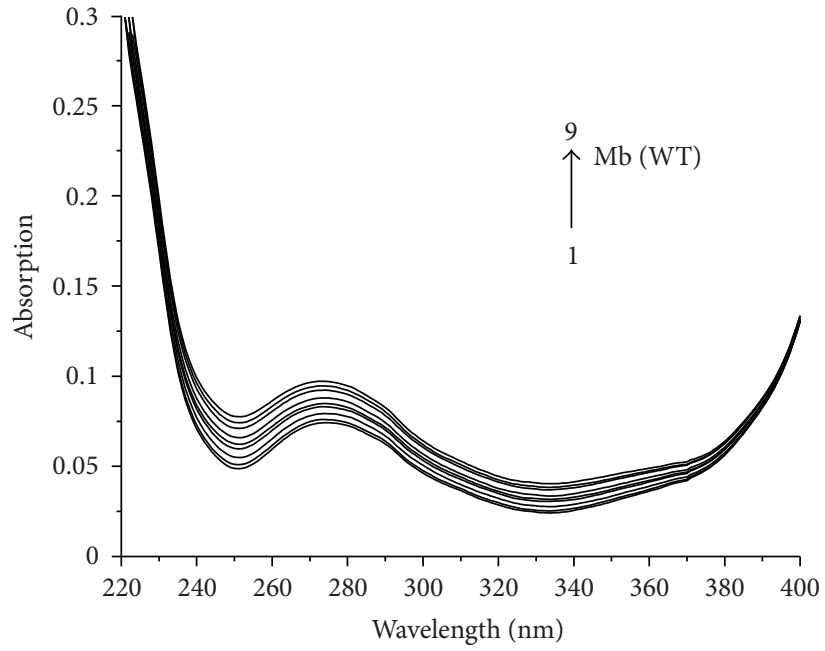

(a)

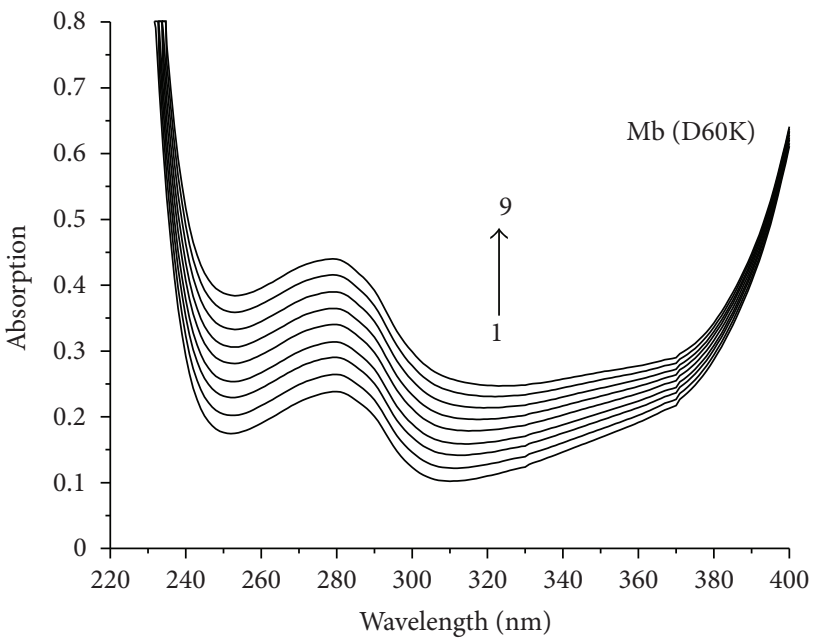

(c)

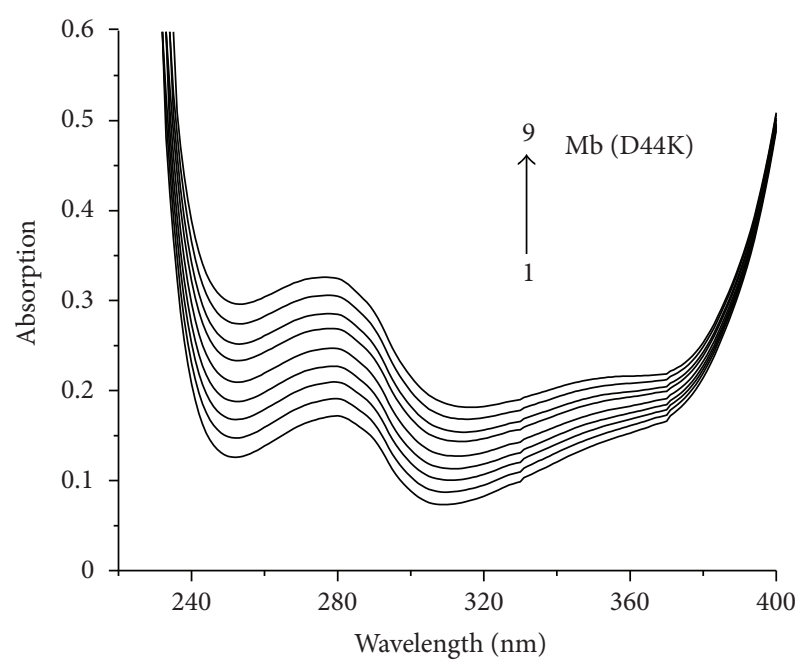

(b)

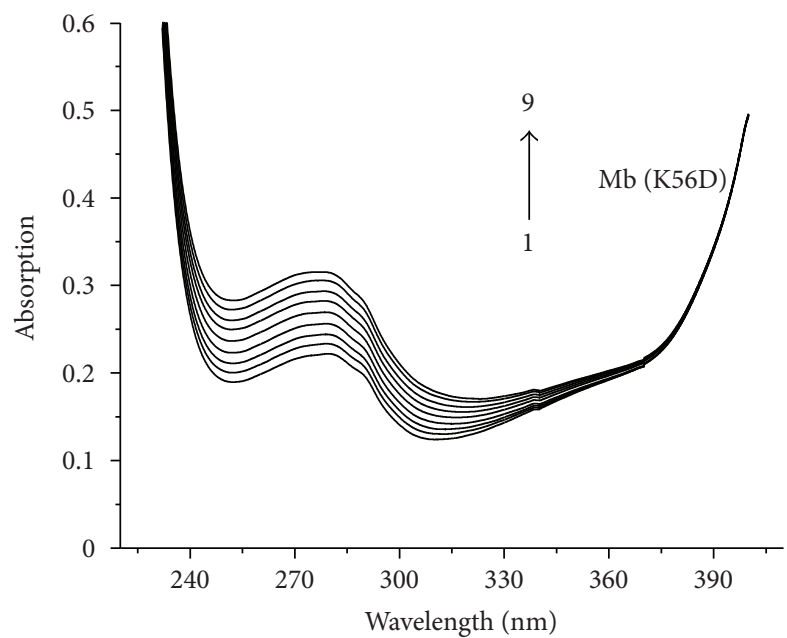

(d)

Figure 1: The effect of Fe(III) on UV absorption spectra of Mb (WT), Mb (D44K), Mb (D60K), and Mb (K56D) (298 K) $C_{\mathrm{Mb}}=$ $5 \times 10^{-6} \mathrm{~mol} \cdot \mathrm{L}^{-1}, 1-9 . \mathrm{C}(\mathrm{Fe}(\mathrm{III})) / 10^{-6} \mathrm{~mol} \cdot \mathrm{L}^{-1}=0,1,2,3,4,5,6,7,8, C_{(\mathrm{Mb}(\mathrm{D} 44 \mathrm{~K}))}, C_{(\mathrm{Mb}(\mathrm{D} 60 \mathrm{~K}))}, C_{(\mathrm{Mb}(\mathrm{K} 56 \mathrm{D}))}=5 \times 10^{-6} \mathrm{~mol} \cdot \mathrm{L}^{-1}, \mathrm{C}$ $(\mathrm{Fe}(\mathrm{III})) / 10^{-6} \mathrm{~mol} \cdot \mathrm{L}^{-1}=0,0.5,1,1.5$.

In (1), $F_{0}$ and $F$ are the fluorescence intensity of the protein solution with quenching body $Q$ not added or added, respectively, $K_{q}$ is the bimolecular quenching constant, $\tau_{0}$ is the average life expectancy of the fluorescent molecules when quenching body does not exist, $K_{s v}$ is the dynamic quenching constant, and $[Q]$ is the concentration of quenching body $Q$.

The fluorescence quenching was measured at three different temperatures $(289,298$, and $313 \mathrm{~K}$ ), and (1) was applied for data processing. The results are shown in Figure 3. Within the concentration dimension of our experiment, when the concentration of $\mathrm{Fe}(\mathrm{III})$ increases, the SternVolmer curve shows good linear relationship, and the slope of the straight line decreases with temperature increasing. It is demonstrated that the fluorescence quenching mechanisms of $\mathrm{Fe}(\mathrm{III})$ on $\mathrm{Mb}$ (WT), $\mathrm{Mb}$ (D44K), $\mathrm{Mb}$ (D60K) and $\mathrm{Mb}$ (K56D) are attributed to static quenching, respectively. Table 1 shows the fluorescence quenching constants of Fe(III) for various kinds of Mbs. All of the, $K_{q} s$, are greater than maximum diffusion or collision quenching constant $2 \times$ $10^{10} \mathrm{~L} \cdot \mathrm{mol}^{1} \mathrm{~s}^{1}$ [24] between the various types of quenching body and the biological macromolecules. These data further show that the fluorescence quenching mechanisms of Fe(III) with various $\mathrm{Mbs}$ are not dynamic quenching but static quenching. The order of magnitude of $\mathrm{Fe}(\mathrm{III})$ on dynamic quenching constant and bimolecular quenching constant of the Mbs is the same, but the value of the mutant is greater than the wild type.

For static quenching, a new compound forms between the quenching molecule and the fluorescent substance molecules, which is according to the following double reciprocal equation of Lineweaver-Burk [15]:

$$
\left(F_{0}-F\right)^{-1}=F_{0}^{-1}+K_{a}^{-1} \cdot F_{0}^{-1}[Q]^{-1} .
$$

See results in Figure 4 and Table 2. 


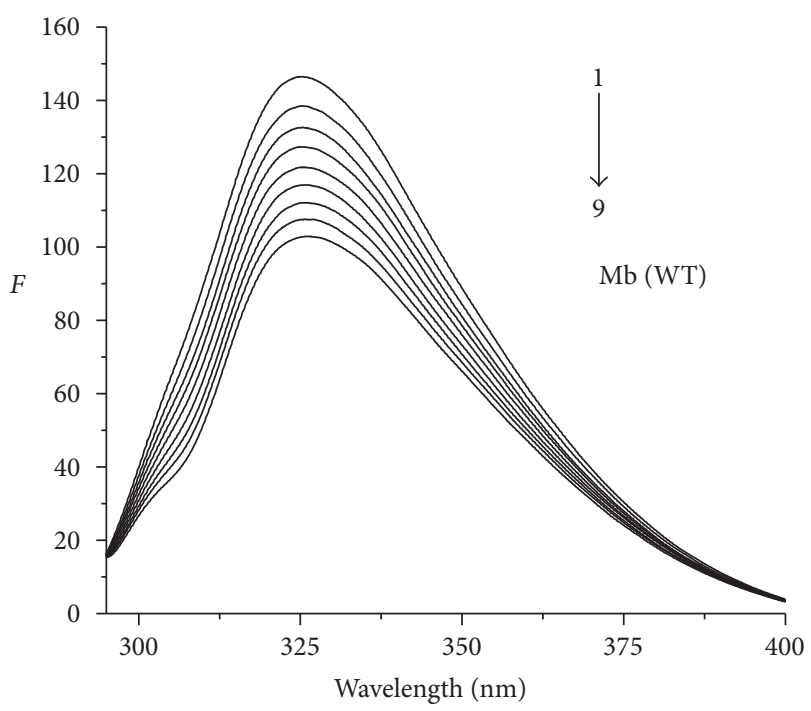

(a)

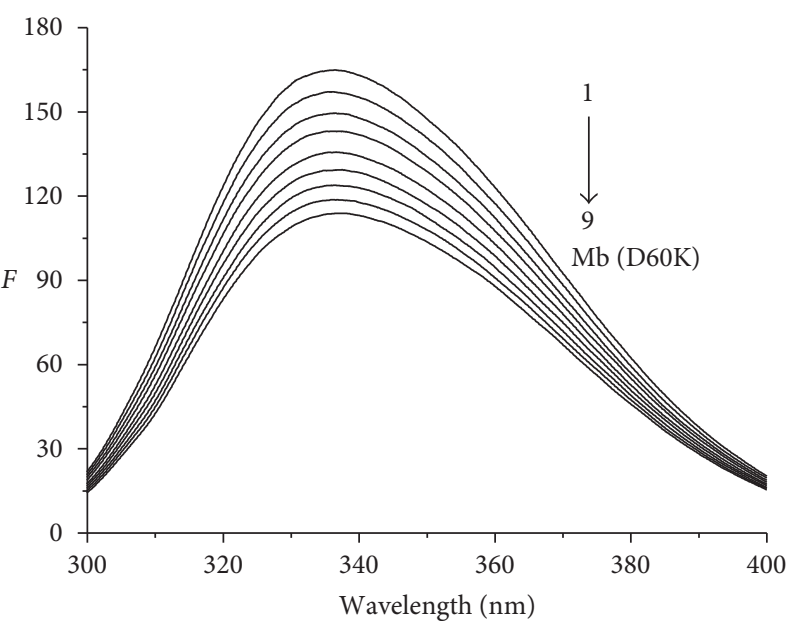

(c)

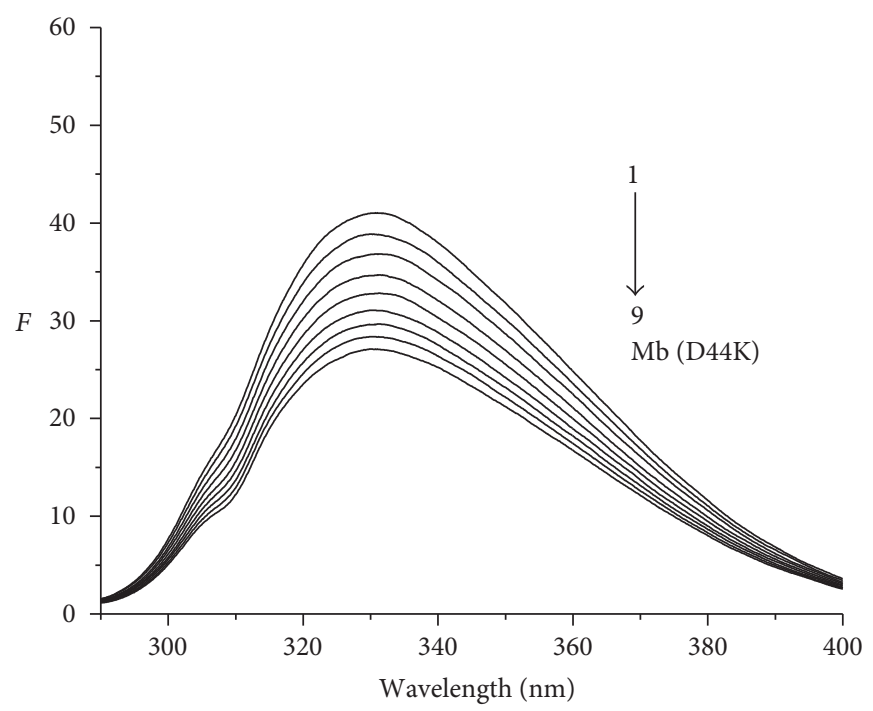

(b)

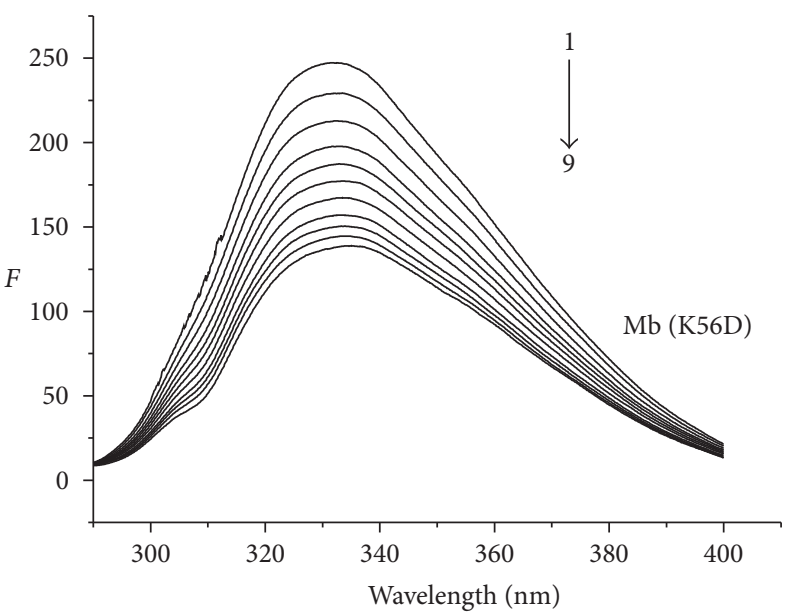

(d)

Figure 2: Effect of $\mathrm{Fe}(\mathrm{III})$ on the fluorescence spectra of $\mathrm{Mbs}\left(25^{\circ} \mathrm{C}\right) . \mathrm{C}\left(\mathrm{Mb}(\mathrm{WT}, \mathrm{D} 44 \mathrm{~K}, \mathrm{D} 60 \mathrm{~K}): 5 \times 10^{-6} \mathrm{~mol} \cdot \mathrm{L}^{-1}, 1-9, \mathrm{C}\right.$ $(\mathrm{Fe}(\mathrm{III})) / 10^{-5} \mathrm{~mol} \cdot \mathrm{L}^{-1}: 0,0.5,1,1.5,2,2.5,3,3.5$, and 4 , resp. $C(\mathrm{Mb}(\mathrm{K} 56 \mathrm{D})): 5 \times 10^{-6} \mathrm{~mol} \cdot \mathrm{L}^{-1} ; 1-9, C(\mathrm{Fe}(\mathrm{III})) / 10^{-6} \mathrm{~mol} \cdot \mathrm{L}^{-1}: 0,1,2,3$, $4,5,6,7,8$, and 9 , respectively.

The double reciprocal curve linear of the LineweaverBurk is shown in Figure 4 and Table 2. All of the binding constant value is high, and the different temperatures affect on the binding constants at a certain extent, which indicates that $\mathrm{Fe}(\mathrm{III})$ and $\mathrm{Mbs}$ has formed stable complex. The binding constants of $\mathrm{Fe}$ (III) to fluorescence quenching of myoglobin have the same order of magnitude, but the mutant value is greater than wild type.

(2) Binding Constants and Number of Binding Sites. For static quenching, it is assumed that biological macromolecules has $n$ identical and independent binding sites, the relationship between fluorescence intensity and quenching body can be derived from the formula of the binding constant between fluorescent molecules and quenching molecules [25, 26] as

$$
\lg \left[\frac{F_{0}-F}{F}\right]=\lg K+n \lg [Q] .
$$

$\lg \left[\left(F_{0}-F\right) / F\right]$ to $\lg [Q]$ plot (Figure 5), the binding constant $K$ and binding site number $n$ of the quenching body and fluorescent molecules can be calculated according to the slope and intercept of the straight line. As it can be seen from Table 3, the binding constants obtained by this method basically conform to $K_{\mathrm{a}}$ value obtained from the LineweaverBurk figure, binding ability decreases with the increasing temperature, the average numbers of binding sites of $\mathrm{Fe}(\mathrm{III})$ and $\mathrm{Mb}(\mathrm{WT}) \mathrm{Mb}(\mathrm{D} 44 \mathrm{~K}), \mathrm{Mb}(\mathrm{D} 60 \mathrm{~K})$, and $\mathrm{Mb}(\mathrm{K} 56 \mathrm{D})$ are 


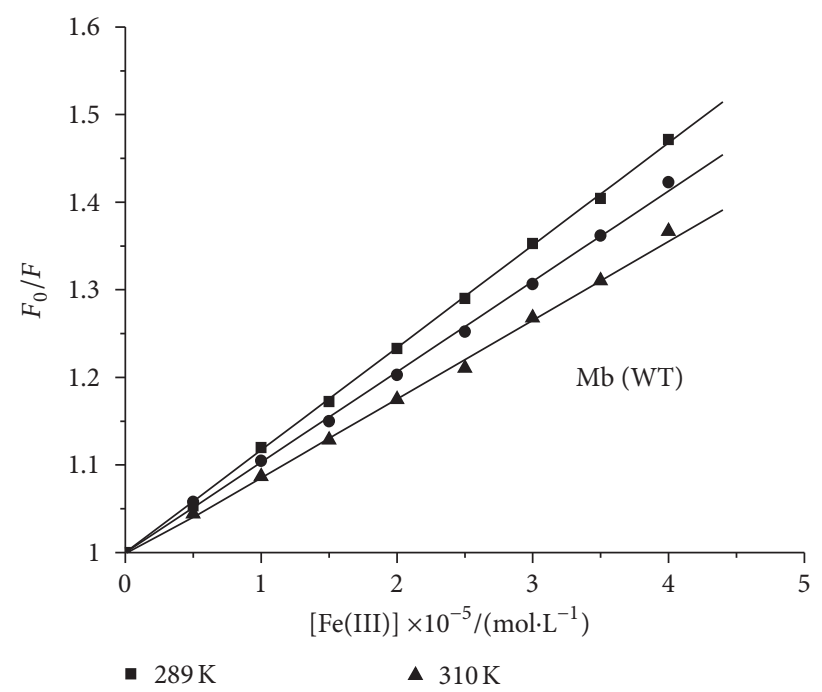

(a)

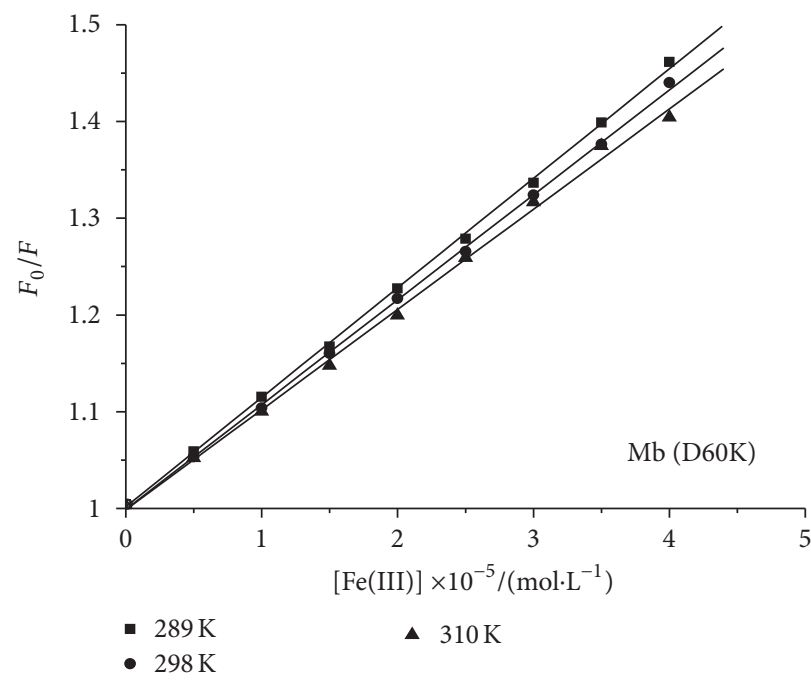

(c)

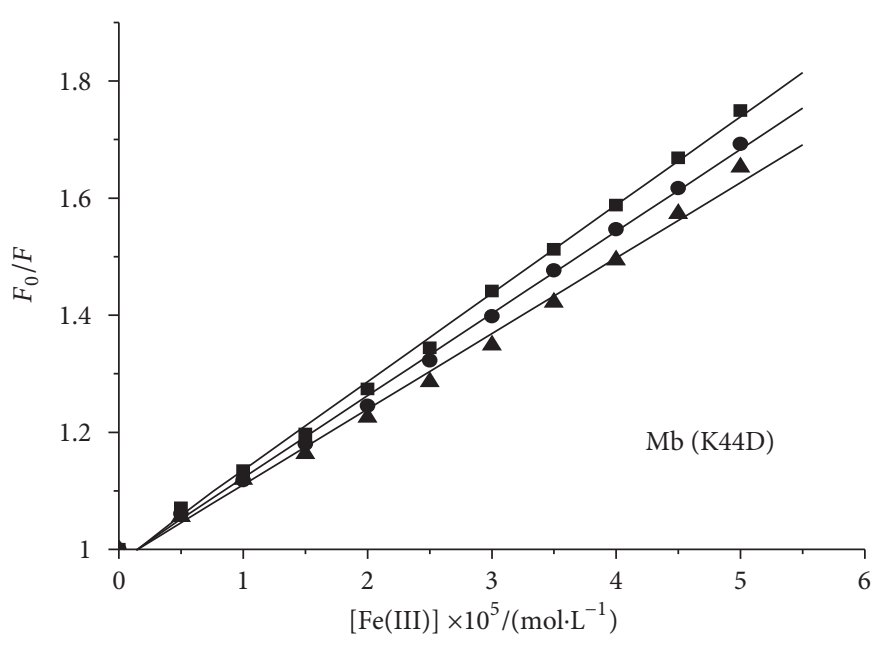

- $289 \mathrm{~K}$

- $298 \mathrm{~K}$

- $310 \mathrm{~K}$

(b)

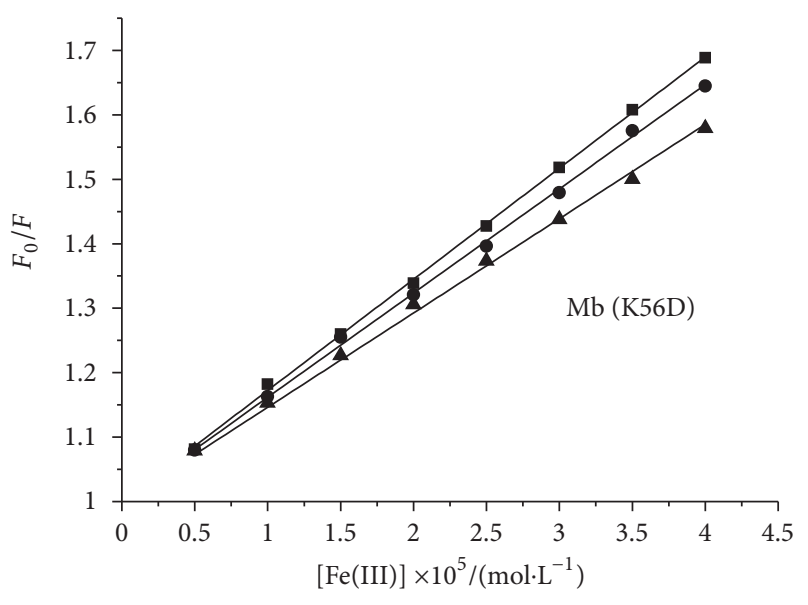

- $289 \mathrm{~K}$

- $298 \mathrm{~K}$

(d)

Figure 3: Stern-Volmer plot of several Mbs quenched by Fe(III) at different temperatures.

$1.0121,1.0334,1.0103$, and 0.9894 , respectively, which are approximately equal to 1 .

3.1.3. Types of Interaction Force. The interaction force between quenching body and biological macromolecules mainly comes from van der Waals' force, electrostatic forces, hydrogen bonding, and hydrophobic [25]. Enthalpy can be taken as a constant in our experiment. Therefore, the reaction of enthalpy change, free energy change, and entropy change can be calculated based on the following thermodynamic formula $[27,28]$ :

$$
\begin{aligned}
\ln k_{a} & =-\frac{\Delta H}{R T}+\frac{\Delta S}{R}, \\
\Delta G & =\Delta H-T \Delta S,
\end{aligned}
$$

where $K$ is the static quenching constant, $T$ is the experimental temperature, and $\Delta H, \Delta G$, and $\Delta S$ are, respectively the enthalpy, free energy change, and entropy change. The calculated results are shown in Table 4.

Table 4 shows that four kinds of the Mbs perform similar natures $\Delta H<0, \Delta G<0, \Delta S>0 . \Delta H<0, \Delta G$ $<0$, which indicate that the combination of $\mathrm{Fe}$ (III) and Mbs is exothermic process and spontaneous process, $\Delta H<$ $0, \Delta S>0$ indicate that the main force is the electrostatic force [15]. The enthalpy changes $\Delta H$ between $\mathrm{Fe}(\mathrm{III})$ and $\mathrm{Mb}(\mathrm{WT})$ or $\mathrm{Mb}(\mathrm{D} 44 \mathrm{~K})$ or $\mathrm{Mb}(\mathrm{D} 60 \mathrm{~K})$ or $\mathrm{Mb}$ (K56D) are $62.36 \%, 35.07 \%, 20.71 \%$, and $17.92 \%$, respectively, at $298 \mathrm{~K}$. The contribution from the entropy change $\Delta S$ are $37.64 \%, 64.93 \%, 79.29 \%$ and $82.08 \%$, respectively at $298 \mathrm{~K}$. The enthalpy change contribution of mutants becomes weak, while entropy change contribution becomes strong. Thus entropy driving force cannot be ignored. 


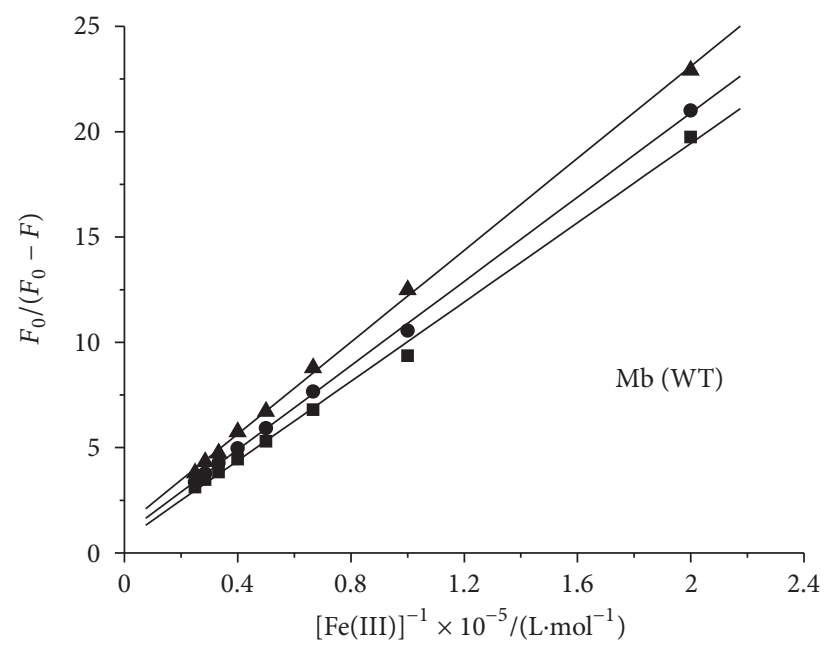

- $289 \mathrm{~K}$

- $298 \mathrm{~K}$

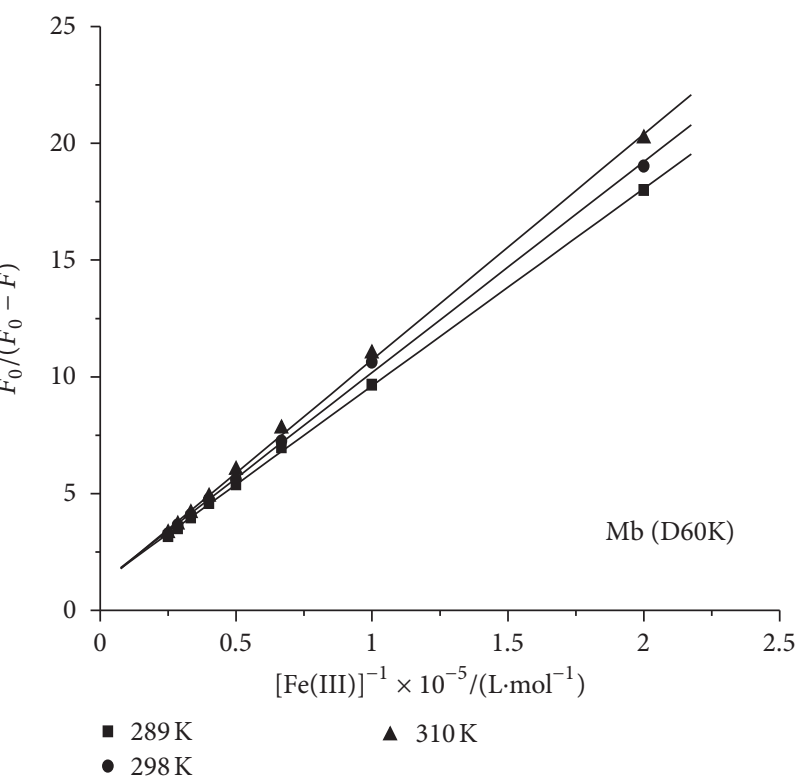

(c)

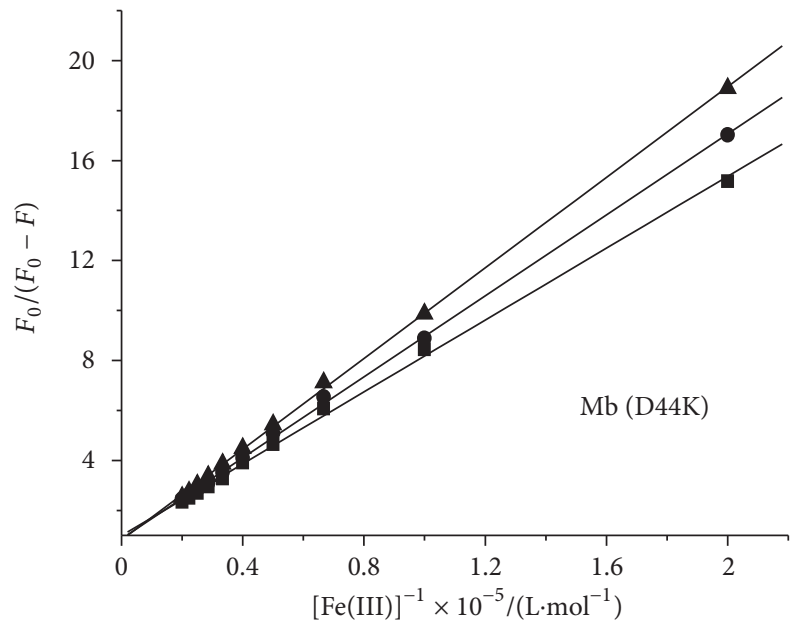

- $289 \mathrm{~K} \quad \boldsymbol{\Delta} 310 \mathrm{~K}$

(b)

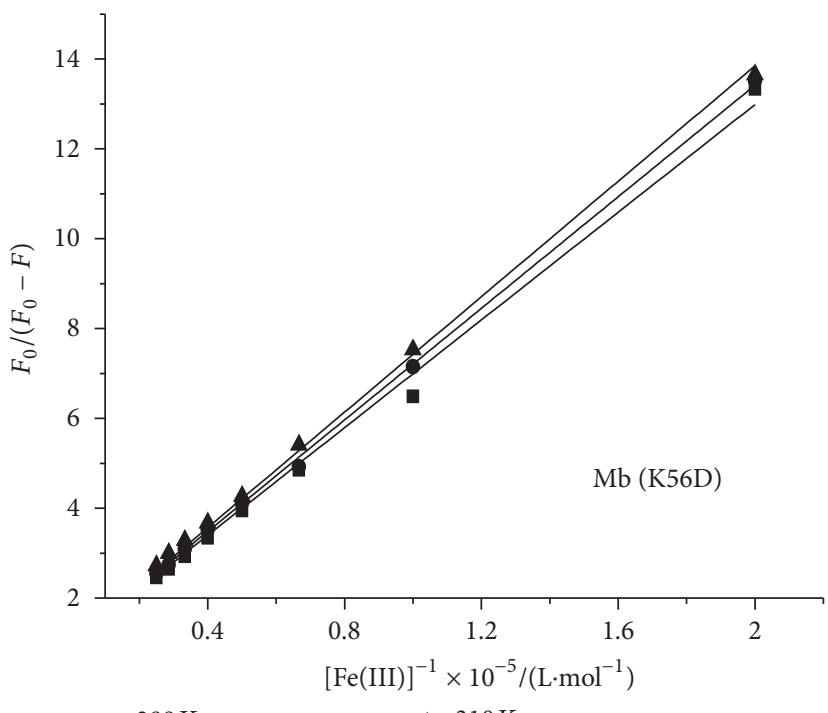

- $289 \mathrm{~K}$

- $298 \mathrm{~K}$
A $310 \mathrm{~K}$

(d)

FIGURE 4: Lineweaver-Burk plot of Mbs quenched by Fe(III) at different temperatures.

3.1.4. Action Distance. Figure 6 shows the overlays of fluorescence spectra of different myoglobin and absorption spectra of $\mathrm{Fe}(\mathrm{III})$ whose molar ratios are $1: 1$, respectively. According to the Förster dipole-dipole nonradiative energy transfer theory $[17,29]$, the binding distances of the tryptophan residues (in wild type, $\mathrm{Mb}(\mathrm{D} 44 \mathrm{~K}), \mathrm{Mb}(\mathrm{D} 60 \mathrm{~K})$ and $\mathrm{Mb}(\mathrm{K} 56 \mathrm{D})$ ) and $\mathrm{Fe}(\mathrm{III})$ are $3.18 \mathrm{~nm}, 3.05 \mathrm{~nm}, 3.15 \mathrm{~nm}$, and $2.38 \mathrm{~nm}$, respectively, which indicate that the interacted distance of mutated myoglobin and metal ions Fe(III) becomes smaller. All binding distances are less than $7 \mathrm{~nm}$, which indicates that nonradiative energy transfer can occur between Mbs and $\mathrm{Fe}$ (III). The above data have proved that the Fe(III) and proteins formed the complexes without fluorescence, so the energy transfer of them should be attributed to the intramolecular nonradiative energy transfer [27].

3.2. The Comparison of Experimental Data Between a Variety of Myoglobin and $\mathrm{Fe}$ (III) Interactions. Table 5 shows that the strength of the combination between $\mathrm{Fe}$ (III) and protein is as follows: $\mathrm{Mb}(\mathrm{K} 56 \mathrm{D})>\mathrm{Mb}(\mathrm{D} 44 \mathrm{~K})>\mathrm{Mb}(\mathrm{D} 60 \mathrm{~K})>\mathrm{Mb}$ (WT), the distances of combination are as follows: $\mathrm{Mb}$ (WT) $>\mathrm{Mb}(\mathrm{D} 60 \mathrm{~K})>\mathrm{Mb}(\mathrm{D} 44 \mathrm{~K})>\mathrm{Mb}(\mathrm{K} 56 \mathrm{D})$. Thus, the surface amino acid residues of Asp56, Asp44, and Lys60 can affect myoglobin's function. The mutants change the volume of residue side chain, which make close residue side chains 


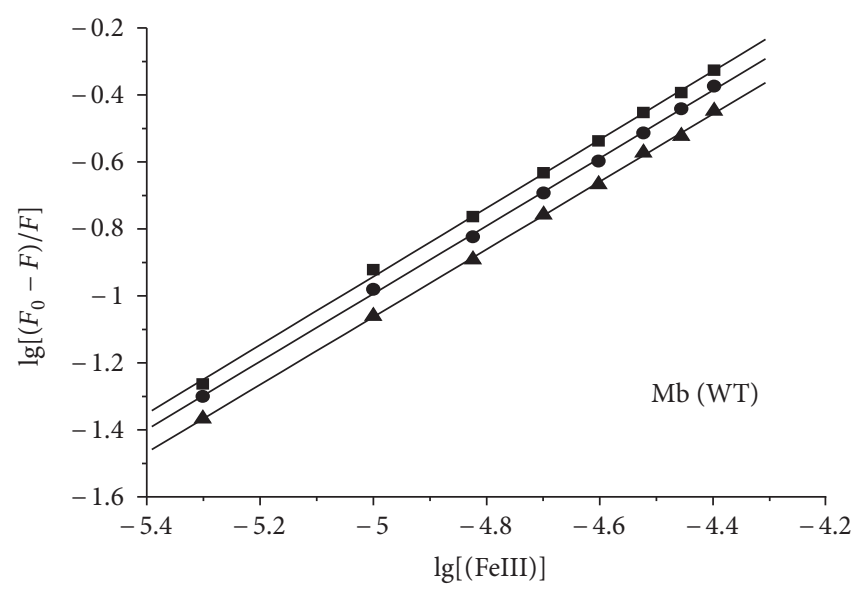

- $289 \mathrm{~K}$

- $298 \mathrm{~K}$

- $310 \mathrm{~K}$

(a)

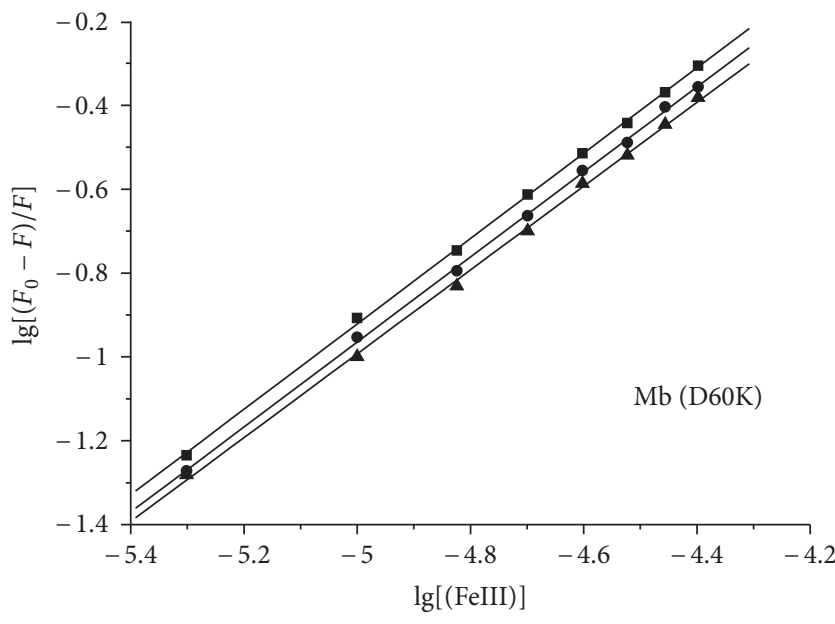

- $289 \mathrm{~K}$

- $298 \mathrm{~K}$

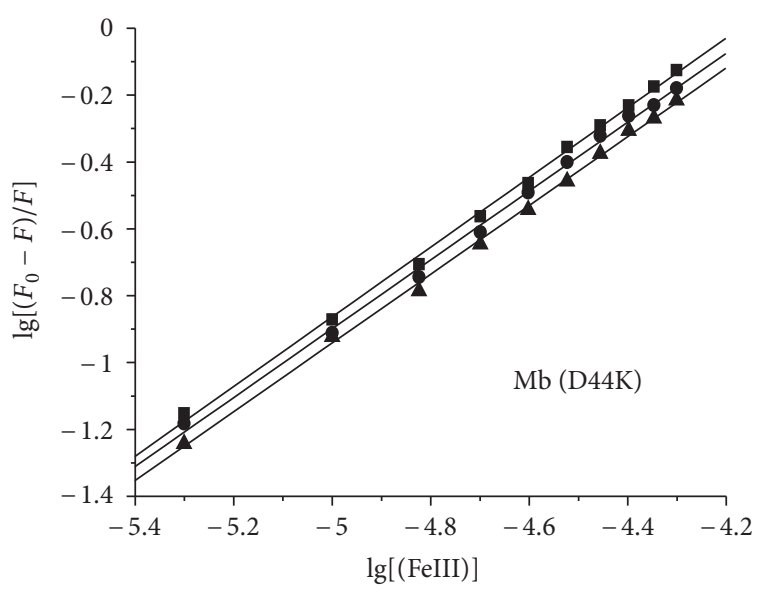

- $289 \mathrm{~K}$

- $298 \mathrm{~K}$

(b)

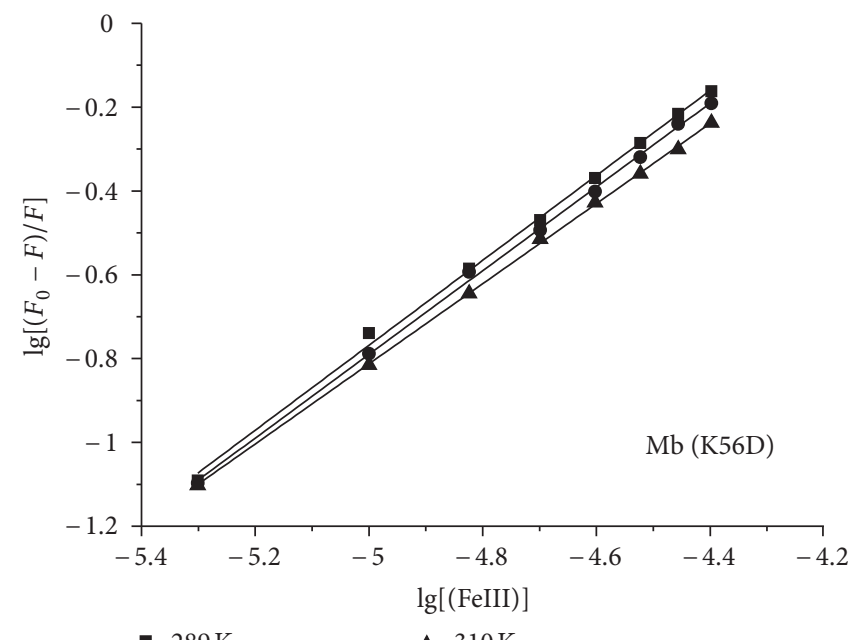

- $289 \mathrm{~K}$

- $298 \mathrm{~K}$

(d)

FIgURE 5: Double-lg plot at different temperatures.

direction change, even make conformation of the side chains of these mutant residues and several other residues' main chains change. Mb (K56D) has more negative charge after it was mutated, which significantly enhances its binding ability with positive-electric Fe(III). Thus, the amino acids on the surface of protein have a definite impact on protein's function $[30,31]$.

3.3. Structure Comparison. In order to further study the effect of surface amino acids on function and structure of myoglobin, here we discuss the relationship between structure and function.

3.3.1. UV Absorption Spectroscopy. $280 \mathrm{~nm}$ absorption peak is formed due to the $\pi-\pi^{*}$ and $n-\pi^{*}$ transition of Myglobin's aromatic amino acids. Figure 7 shows the UV absorption spectra of myoglobin (wild type and mutants). The maximum absorption spectrum of wild-type myoglobin is at $276 \mathrm{~nm}$ position, while the maximum absorption of three mutants is at $280 \mathrm{~nm}$ position (Figure 7). The surface charges of myoglobin change after the surface amino acids were replaced, which affects the internal aromatic amino acid microenvironments, increases it's hydrophobicity, and decreases $\pi-\pi^{*}$ and $n-\pi^{*}$ transition energy, furthermore induces peaks shifted.

3.3.2. Fluorescence Spectroscopy. Fluorescence spectrometric methods have many advantages [32], such as high sensitivity, less volume of sample, high selectivity, and simplicity. It is often used as an important mean to the study of protein conformation changes. Figure 8 shows fluorescence emission spectra of myoglobin (wild type and its mutants). The maximum emission peaks of $\mathrm{Mb}(\mathrm{WT}), \mathrm{Mb}(\mathrm{D} 44 \mathrm{~K}), \mathrm{Mb}$ $(\mathrm{D} 60 \mathrm{~K})$, and $\mathrm{Mb}(\mathrm{K} 56 \mathrm{D})$ are $323 \mathrm{~nm}, 330 \mathrm{~nm}, 336 \mathrm{~nm}$, and $329.6 \mathrm{~nm}$, respectively, in $280 \mathrm{~nm}$ excitation wavelength. The 


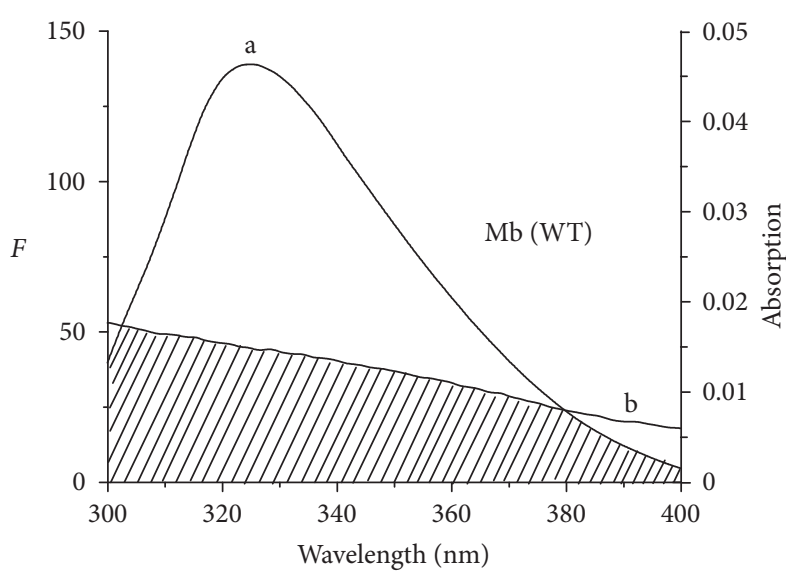

(a)

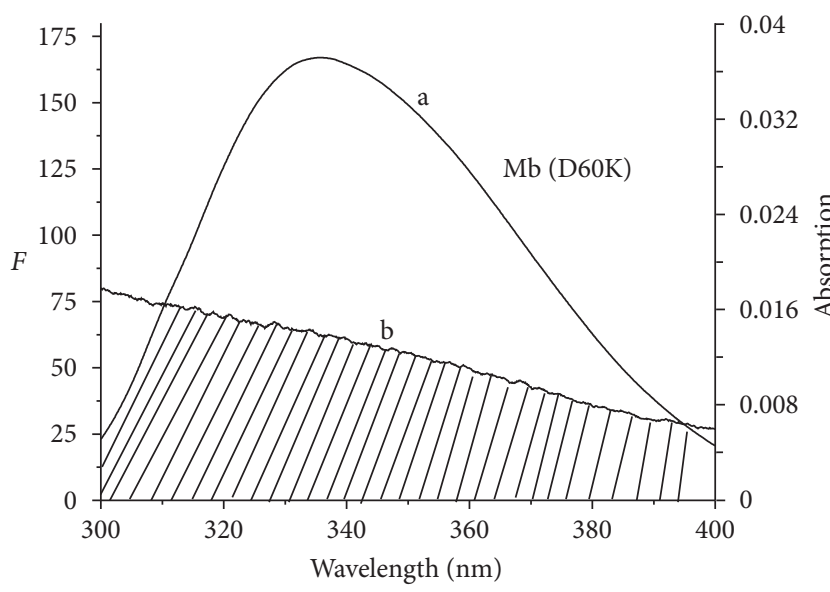

(c)

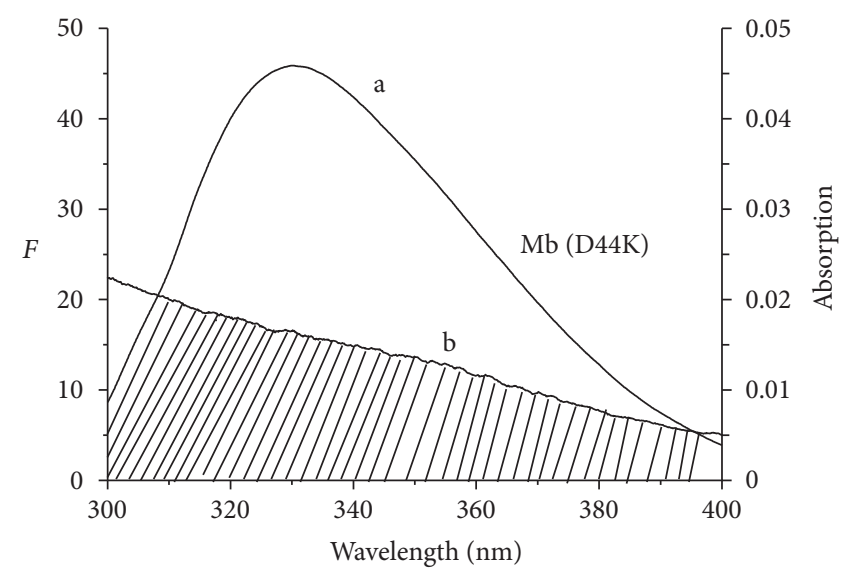

(b)

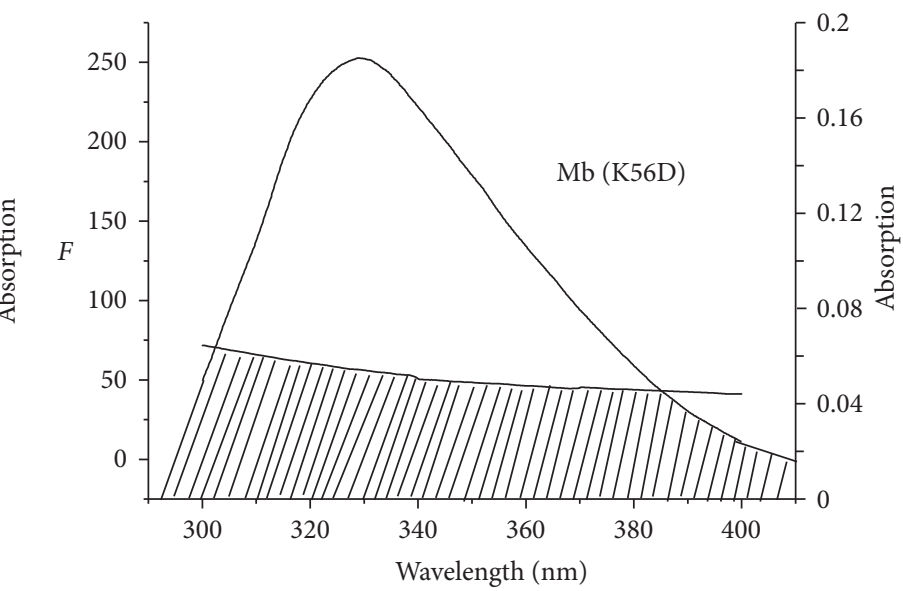

(d)

FIgURE 6: Overlap of the fluorescence spectra of Mbs (a) and the absorption spectra of Fe(III) (b).

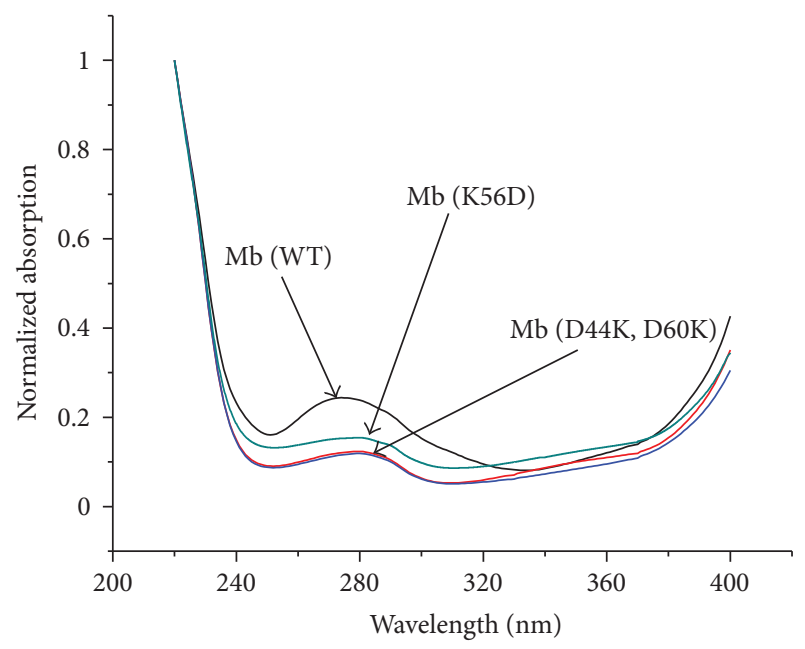

FigURE 7: Absorbance spectra of $5 \mu \mathrm{M}$ myoglobin and mutants.

mutant (D44K, D60K, and K56D) maximum mission peaks red shift compared to wild-type myoglobin. The shift of D60K location is maximal, and shift is $11.2 \mathrm{~nm}$ compared

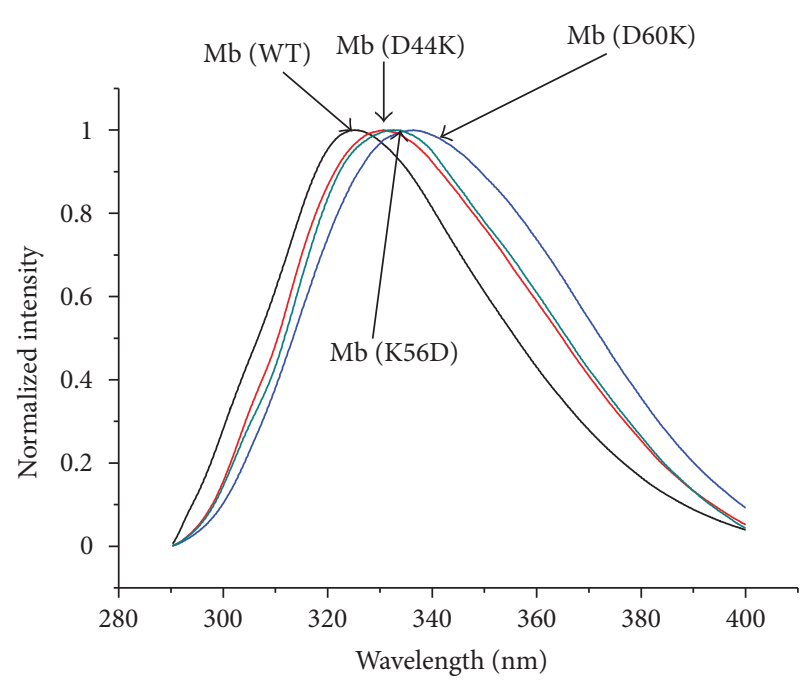

FIGURE 8: Fluorescence spectra of $5 \mu \mathrm{M}$ myoglobin and mutants.

to wild-type Mb. The displaced amino acids on the surface of myoglobin induce the polarity of aromatic amino acid 


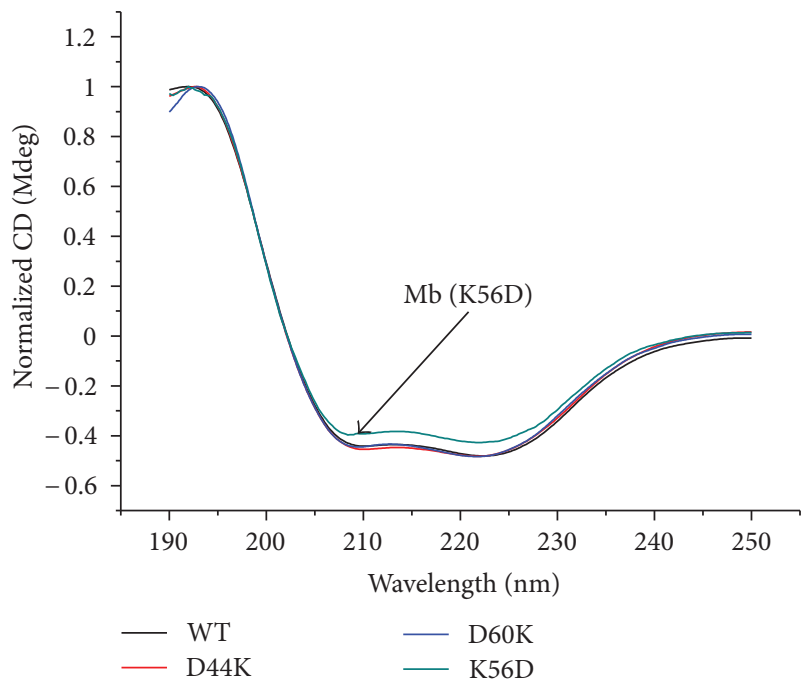

FIGURE 9: CD spectra of $5 \mu \mathrm{M}$ myoglobin and mutants.

TABLE 2: The binding constants $\left(K_{a}\right)$ and relative coefficient $(R)$ in lineweaver-Burk curve.

\begin{tabular}{lcc}
\hline $\mathrm{Mb}$ and mutants & $\mathrm{T} / \mathrm{K}$ & $\mathrm{K}_{a} / \mathrm{L} \cdot \mathrm{mol}^{-1}$ \\
\hline \multirow{3}{*}{$\mathrm{Mb}(\mathrm{WT})$} & 289 & $1.06 \times 10^{4}$ \\
& 298 & $1.00 \times 10^{4}$ \\
& 310 & $0.926 \times 10^{4}$ \\
$\mathrm{Mb}(\mathrm{D} 44 \mathrm{~K})$ & 289 & $1.39 \times 10^{4}$ \\
& 298 & $1.23 \times 10^{4}$ \\
& 310 & $1.10 \times 10^{4}$ \\
$\mathrm{Mb}(\mathrm{D} 60 \mathrm{~K})$ & 289 & $1.18 \times 10^{4}$ \\
& 298 & $1.11 \times 10^{4}$ \\
& 310 & $1.03 \times 10^{4}$ \\
$\mathrm{Mb}(\mathrm{K} 56 \mathrm{D})$ & 289 & $1.67 \times 10^{4}$ \\
& 298 & $1.61 \times 10^{4}$ \\
& 310 & $1.56 \times 10^{4}$ \\
\hline
\end{tabular}

hydrophobic box to be changed, weaken its polarity, reduce its fluorescence energy, and shift emission peak position. The above results are consistent with ultraviolet spectroscopy.

3.3.3. Circular Dichroism Spectroscopy. Figure 9 displays the CD spectra of wild-type and mutant Mbs, and all of them show three peaks in $192 \mathrm{~nm}(+), 202(-)$, and $222(-)$, which are $\alpha$-helix typical characteristic peaks [33-35]. The peak position and the strength for wild type, D44K, and D60K are at the same level, only the strength of the K56D changes slightly. This proves that the surface amino acid changes have little effect on myoglobin second structures.

Therefore, the changes of amino acids on the surface of myoglobin have great impact on its tertiary structure microenvironment, but little effect on the secondary structure. The stability and integrality of proteins' tertiary structure is important for protein to put in practice its function
TABLE 3: The binding constants $(K)$, the binding numbers $(n)$, and their correlations $(R)$ at different temperatures.

\begin{tabular}{lcccc}
\hline Mb mutants & $T / \mathrm{K}$ & $K /\left(\mathrm{L} \cdot \mathrm{mol}^{-1}\right)$ & $n$ & $R$ \\
\hline & 289 & $1.48 \times 10^{4}$ & 1.0226 & 0.9997 \\
$\mathrm{Mb}(\mathrm{WT})$ & 298 & $1.18 \times 10^{4}$ & 1.0128 & 0.9995 \\
& 310 & $9.81 \times 10^{4}$ & 1.0009 & 0.9994 \\
\hline & 289 & $2.23 \times 10^{4}$ & 1.0424 & 0.9989 \\
$\mathrm{Mb}(\mathrm{D} 44 \mathrm{~K})$ & 298 & $1.78 \times 10^{4}$ & 1.0296 & 0.9986 \\
& 310 & $1.58 \times 10^{4}$ & 1.0282 & 0.9990 \\
\hline & 289 & $1.47 \times 10^{4}$ & 1.0180 & 0.9989 \\
$\mathrm{Mb}(\mathrm{D} 60 \mathrm{~K})$ & 298 & $1.28 \times 10^{4}$ & 1.0135 & 0.9986 \\
& 310 & $1.12 \times 10^{4}$ & 0.9994 & 0.9990 \\
\hline & 289 & $1.99 \times 10^{4}$ & 1.0133 & 0.999 \\
$\mathrm{Mb}(\mathrm{K} 56 \mathrm{D})$ & 298 & $1.6 \times 10^{4}$ & 0.9989 & 0.999 \\
& 310 & $0.9 \times 10^{4}$ & 0.956 & 1 \\
\hline
\end{tabular}

TABLE 4: The thermodynamic parameters between $\mathrm{Fe}(\mathrm{III})$ and $\mathrm{Mb}$ mutants.

\begin{tabular}{|c|c|c|c|}
\hline Mb mutants & $\Delta H / \mathrm{KJ} \cdot \mathrm{mol}^{-1}$ & $\Delta G / \mathrm{KJ} \cdot \mathrm{mol}^{-1}$ & $\Delta S / \mathrm{J} \cdot \mathrm{mol}^{-1} \cdot \mathrm{K}^{-1}$ \\
\hline \multirow{3}{*}{$\mathrm{Mb}(\mathrm{WT})$} & \multirow{3}{*}{-14.53} & -23.03 & \multirow{3}{*}{29.44} \\
\hline & & -23.30 & \\
\hline & & -23.65 & \\
\hline \multirow{3}{*}{$\mathrm{Mb}(\mathrm{D} 44 \mathrm{~K})$} & \multirow{3}{*}{-8.20} & -22.91 & \multirow{3}{*}{50.95} \\
\hline & & -23.38 & \\
\hline & & -23.98 & \\
\hline \multirow{3}{*}{$\mathrm{Mb}(\mathrm{D} 60 \mathrm{~K})$} & \multirow{3}{*}{-4.78} & -22.53 & \multirow{3}{*}{61.42} \\
\hline & & -23.08 & \\
\hline & & -23.82 & \\
\hline \multirow{3}{*}{$\mathrm{Mb}(\mathrm{K} 56 \mathrm{D})$} & \multirow{3}{*}{-4.314} & -23.49 & \multirow{3}{*}{66.34} \\
\hline & & -24.08 & \\
\hline & & -25.08 & \\
\hline
\end{tabular}

TABLE 5: The comparison of experimental data of $\mathrm{Mb}$ (WT) and $\mathrm{Mb}$ mutants, respectively, $\left(25^{\circ} \mathrm{C}\right)$.

\begin{tabular}{lcccc}
\hline $\mathrm{Mbs}$ & $K_{q}$ & $K_{a}$ & $n$ & $r$ \\
\hline $\mathrm{Mb}(\mathrm{WT})$ & $1.04 \times 10^{12}$ & $1.00 \times 10^{4}$ & 1.0128 & 3.18 \\
$\mathrm{Mb}(\mathrm{D} 60 \mathrm{~K})$ & $1.09 \times 10^{12}$ & $1.11 \times 10^{4}$ & 1.0135 & 3.15 \\
$\mathrm{Mb}(\mathrm{D} 44 \mathrm{~K})$ & $1.40 \times 10^{12}$ & $1.23 \times 10^{4}$ & 1.0296 & 3.05 \\
$\mathrm{Mb}(\mathrm{K} 56 \mathrm{D})$ & $2.36 \times 10^{12}$ & $2.13 \times 10^{4}$ & 1.0525 & 2.38 \\
\hline
\end{tabular}

accurately. The little changes in the three-dimensional structure of the microenvironment have large effect to its function.

\section{Consclusion}

The above studies show that $\mathrm{Fe}(\mathrm{III})$ and Mbs (wild type and mutants) formed new complexes without fluorescence, which cause protein's fluorescence quenched. All of quenching types are static fluorescence quenching, the acting forces are electrostatic interactions, and the binding constants are 1 . The three-dimensional structure of mutant proteins changes after mutation, which also leads to changing interactions 
between $\mathrm{Fe}(\mathrm{III})$ and Mbs changed. At the same temperature, the binding distances of $\mathrm{Fe}(\mathrm{III})$ and $\mathrm{Mbs}$ are as follows: $\mathrm{Mb}(\mathrm{WT})>\mathrm{Mb}(\mathrm{D} 60 \mathrm{~K})>\mathrm{Mb}(\mathrm{D} 44 \mathrm{~K})>\mathrm{Mb}(\mathrm{K} 56 \mathrm{D})$, and protein binding strength: $\mathrm{Mb}(\mathrm{K} 56 \mathrm{D})>\mathrm{Mb}(\mathrm{D} 44 \mathrm{~K})>\mathrm{Mb}$ $(\mathrm{D} 60 \mathrm{~K})>\mathrm{Mb}(\mathrm{WT})$. In short, it is concluded that $\mathrm{Fe}(\mathrm{III})$ has stronger interactions with mutant proteins compared with the experimental data of the wild-type myoglobin. Displacement of Asp44, Asp60, and Lys56 amino acids on the surface of myoglobin have a certain impact on the threedimensional structure and function of myoglobin.

\section{Acknowledgments}

This project was supported by the National Natural Science Foundation of China (no. 20871024) the Fund of Liaoning Innovative Research Team in Generic University, China (nos. 2008T005, 2009T003, and 2010T003).

\section{References}

[1] P. Yang and F. Gao, Theory of Biologic Inorganic Chemistry, Beijing, China, 2002.

[2] J. Y. Wang, S. G. Zhu, and C. F. Xu, Biochemistry, Beijing, China, 2002.

[3] J. Y. Wang, D. Liu, Q. Tang et al., "Probe of the effect of Asp44 on the stability of myoglobin by circular dichroism spectropolarimeter," Spectroscopy and Spectral Analysis, vol. 28, no. 2, pp. 426-429, 2008.

[4] B. M. Hoffman, L. M. Celis, D. A. Cull et al., "Differential influence of dynamic processes on forward and reverse electron transfer across a protein-protein interface," Proceedings of the National Academy of Sciences of the United States of America, vol. 102, no. 10, pp. 3564-3569, 2005.

[5] J. M. Nocek, A. K. Knutson, P. Xiong, N. Petlakh Co, and B. M. Hoffman, "Photoinitiated singlet and triplet electron transfer across a redesigned [Myoglobin, Cytochrome b 5] interface," Journal of the American Chemical Society, vol. 132, no. 17, pp. 6165-6175, 2010.

[6] P. Xiong, J. M. Nocek, J. Vura-Weis, J. V. Lockard, M. R. Wasielewski, and B. M. Hoffman, "Faster interprotein electron transfer in a [myoglobin, b5] complex with a redesigned interface," Science, vol. 330, no. 6007, pp. 1075-1078, 2010.

[7] J. Y. Ma, X. F. Zheng, and Q. Tang, "Spacelike Willmore surfaces in 4-dimensional Lorentzian space forms," Science in China A, vol. 51, no. 9, pp. 141-149, 2008.

[8] J. Y. Ma, J. Ma, and X. F. Zheng, "Spectroscopic investigation of the photo-induced deoxygenzation of myologin and it's mutantnat Mb (D44K)," Chinese Journal of Analytical Chemistry, vol. 36, pp. 435-439, 2008.

[9] Y. Y. Zhang, H. Y. Cao, and Q. Tang, "Interactions between different classes of surfactants and metmyoglobin," Acta PhysicoChimica Sinica, vol. 27, no. 12, pp. 2907-2914, 2011.

[10] Y. W. Li, H. Y. Cao, and Q. Tang, "Spectroscopy and stoppedflow/fluorescence studies on the interactions of myoglobin and its mutant (D60K) with surfactants," Acta Physico-Chimica Sinica, vol. 26, no. 6, pp. 1687-1692, 2010.

[11] Q. Y. Zhi, Q. Tang, and H. Y. Cao, "Comparison between myoglobin and its mutant(D60K) interacting with hydrogen peroxide by spectrum," Spectroscopy and Spectral Analysis, vol. 31, no. 9, pp. 2512-2516, 2011.
[12] K. Hegetschweiler, P. Saltman, C. Dalvit, and P. E. Wright, "Kinetics and mechanisms of the oxidation of myoglobin by $\mathrm{Fe}(\mathrm{III})$ and $\mathrm{Cu}(\mathrm{II})$ complexes," Biochimica et Biophysica Acta, vol. 912, no. 3, pp. 384-397, 1987.

[13] Q. Tang, X. F. Zheng, and J. Y. Wang, "Study on interaction between heme-iron of myoglobin and metal ions by visible spectroscopy(I)," Spectroscopy and Spectral Analysis, vol. 29, no. 7, pp. 1958-1961, 2009.

[14] Q. Tang, H. Y. Cao, and J. Y. Wang, "Study on the effect of temperature and time on the direct interaction between hemeiron of myoglobin and metal ions," Letters in Biotechnology, vol. 22, no. 4, pp. 548-551, 2011.

[15] J. Ma, X. F. Zheng, Q. Tang, Y. J. Yang, X. Sun, and D. B. Gao, "Spectroscopic studies on the interaction of $\mathrm{Cu}^{2+}$ with myoglobin," Chemical Journal of Chinese Universities, vol. 29, no. 2, pp. 258-263, 2008.

[16] H. W. Zhou, H. Y. Cao, and Q. Tang, "Spectral study on the photoreduction of metmyoglobin," Acta Chimica Sinica, vol. 69, no. 13, pp. 1559-1564, 2011.

[17] J. G. Guillemette, Y. Matsushima-Hibiya, T. Atkinson, and M. Smith, "Expression in Escherichia coli of a synthetic gene coding for horse heart myoglobin," Protein Engineering, vol. 4, no. 5, pp. 585-592, 1991.

[18] M. S. Hargrove and J. S. Olson, "The stability of holomyoglobin is determined by heme affinity," Biochemistry, vol. 35, no. 35, pp. 11310-11318, 1996.

[19] X. J. Chang, F. Yang, and L. Zhang, "The interaction of dyaprosium(III) and titanium(IV) with hemoglobin," Journal of Lanzhou University, vol. 40, pp. 62-65, 2004.

[20] C. N. Yan, H. X. Zhang, Y. Liu, P. Mei, K. H. Li, and J. Q. Tong, "Fluorescence spectra of the binding reaction between paraquat and bovine serum albumin," Acta Chimica Sinica, vol. 63, no. 18, pp. 1727-1732, 2005.

[21] T. Wang, Z. Zhao, J. Hua, and J. Zhang, "Characterization of the interaction between reserpine and bovine serum albumin: spectroscopic approaches," Indian Journal of Biochemistry and Biophysics, vol. 48, no. 6, pp. 388-394, 2011.

[22] J. Seetharamappa and B. P. Kamat, "Spectroscopic studies on the mode of interaction of an anticancer drug with bovine serum albumin," Chemical and Pharmaceutical Bulletin, vol. 52, no. 9, pp. 1053-1057, 2004.

[23] Y. M. Yang, Q. L. Hu, Y. L. Fan, and H. Shen, "Study on the binding of luteolin to bovine serum albumin," Spectrochimica Acta A, vol. 69, no. 2, pp. 432-436, 2008.

[24] P. B. Kandagal, J. Seetharamappa, S. Ashoka, S. M. T. Shaikh, and D. H. Manjunatha, "Study of the interaction between doxepin hydrochloride and bovine serum albumin by spectroscopic techniques," International Journal of Biological Macromolecules, vol. 39, no. 4-5, pp. 234-239, 2006.

[25] J. Q. Lu, F. Jin, T. Q. Sun, and X. W. Zhou, "Multispectroscopic study on interaction of bovine serum albumin with lomefloxacin-copper(II) complex," International Journal of Biological Macromolecules, vol. 40, no. 4, pp. 299-304, 2007.

[26] I. Sirangelo, S. Tavassi, P. L. Martelli, R. Casadio, and G. Irace, "The effect of tryptophanyl substitution on folding and structure of myoglobin," European Journal of Biochemistry, vol. 267, no. 13, pp. 3937-3945, 2000.

[27] Y. Q. Wang, H. M. Zhang, and G. C. Zhang, "Studies of the interaction between paraquat and bovine hemoglobin," International Journal of Biological Macromolecules, vol. 41, no. 3, pp. 243-239, 2007. 
[28] G. Zhang, L. Wang, and J. Pan, "Nanoparticles synthesized from soy protein: preparation, characterization, and application for nutraceutical encapsulation," Journal of Agricultural and Food Chemistry, vol. 60, no. 10, pp. 2712-2719, 2012.

[29] S. M. T. Shaikh, J. Seetharamappa, P. B. Kandagal, and D. H. Manjunatha, "In vitro study on the binding of anti-coagulant vitamin to bovine serum albumin and the influence of toxic ions and common ions on binding," International Journal of Biological Macromolecules, vol. 41, no. 1, pp. 81-86, 2007.

[30] C. A. Royer, "Probing protein folding and conformational transitions with fluorescence," Chemical Reviews, vol. 106, no. 5, pp. 1769-1784, 2006.

[31] S. Hui, J. X. Lu, Y. H. Wang, and R. Yi, "Study on the DMECytochrome b5 and its mutants at site of F58," Chinese Science Bulletin, vol. 49, no. 18, pp. 1914-1919, 2004.

[32] N. Greenfield and G. D. Fasman, "Computed circular dichroism spectra for the evaluation of protein conformation," Biochemistry, vol. 8, no. 10, pp. 4108-4116, 1969.

[33] J. C. Croney, D. M. Jameson, and R. P. Learmonth, "Fluorescence spectroscopy in biochemistry: teaching basic principles with visual demonstrations," Biochemistry and Molecular Biology Education, vol. 29, no. 2, pp. 60-65, 2001.

[34] X. C. Shen, H. Liang, and X. W. He, "Recent trends and spectroscopic methods for analysis of the protein conformation with circular dichrosim," Chinese Journal of AnalyticalChemistry, vol. 32, pp. 388-394, 2004.

[35] Y. H. Chen, J. T. Yang, and K. H. Chau, "Determination of the helix and $\beta$ form of proteins in aqueous solution by circular dichroism," Biochemistry, vol. 13, no. 16, pp. 3350-3359, 1974. 

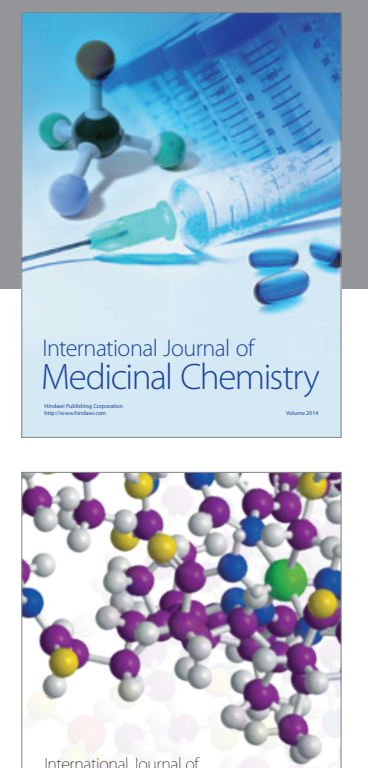

\section{Carbohydrate} Chemistry

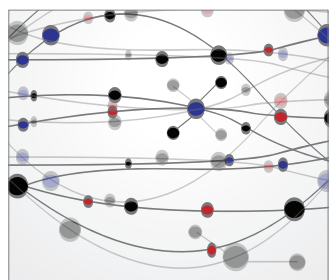

The Scientific World Journal
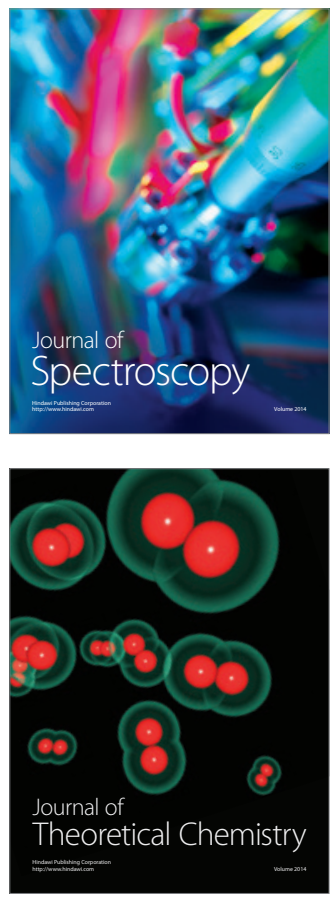
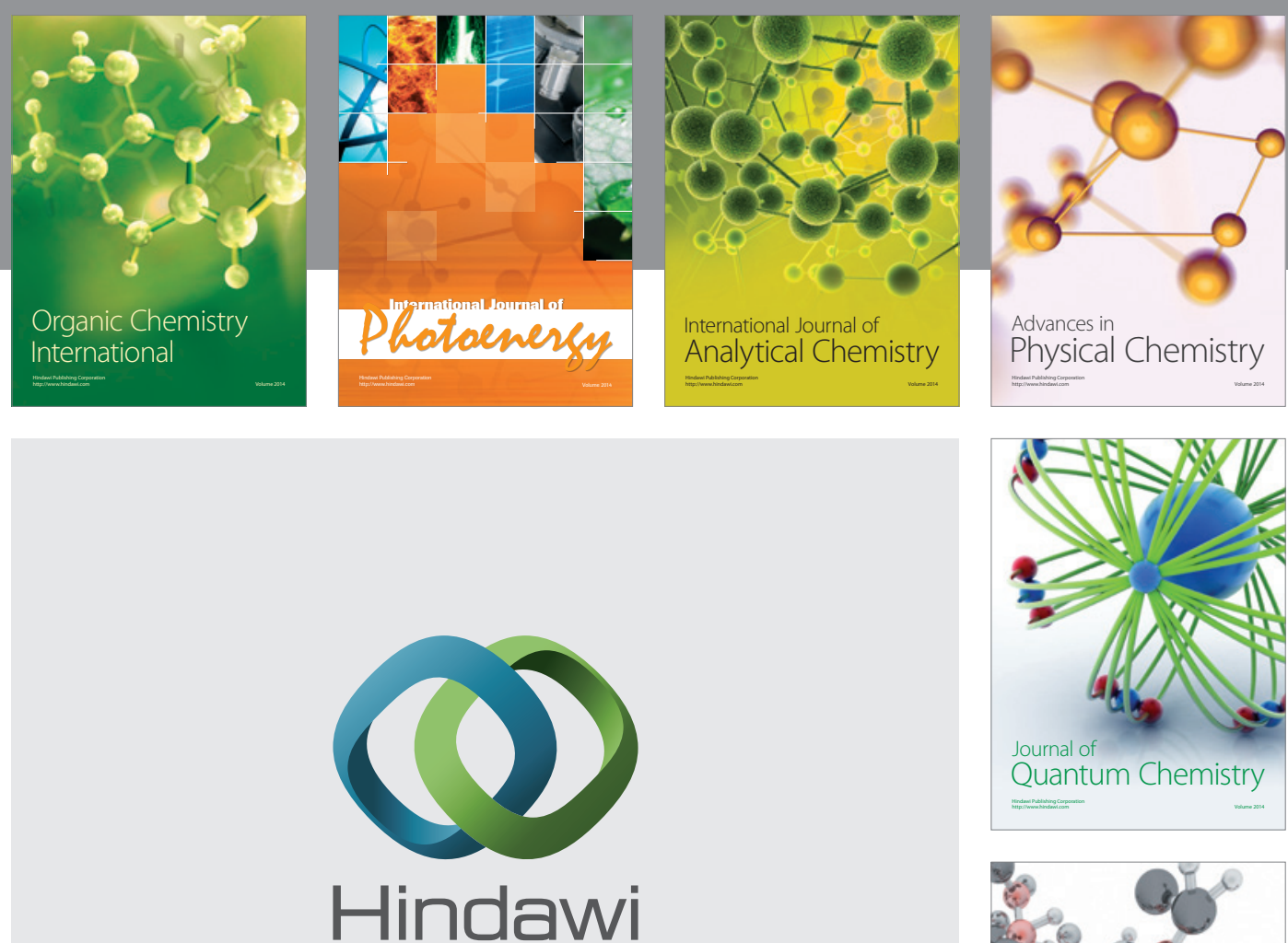

Submit your manuscripts at

http://www.hindawi.com

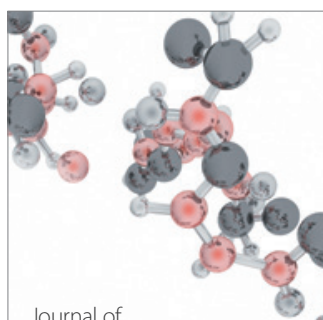

Analytical Methods

in Chemistry

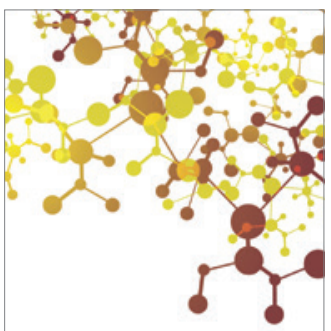

Journal of

Applied Chemistry

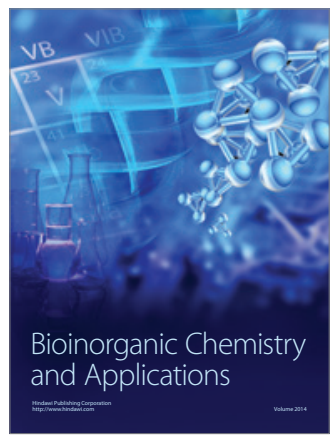

Inorganic Chemistry
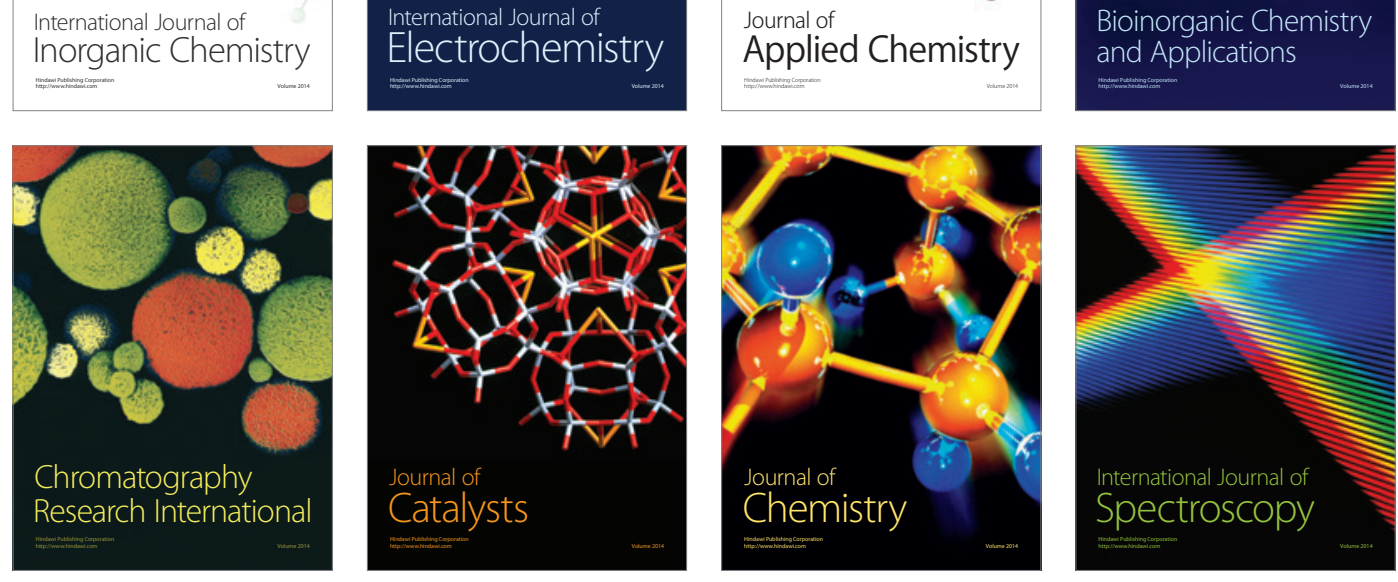